\title{
TANTANGAN DAN SOLUSI PEMBELAJARAN BAHASA INDONESIA DI ERA COVID-19
}

\section{INDONESIAN LEARNING CHALLENGES AND SOLUTIONS IN THE COVID-19 ERA}

\author{
Sujinah* \\ Pendidikan Bahasa dan Sastra Indonesia, Universitas Muhammadiyah Surabaya, \\ Indonesia \\ sujinah@pps.um-surabaya.ac.id \\ *penulis korespondensi
}

\begin{tabular}{ll}
\hline Info Artikel & ABSTRAK \\
\hline Sejarah artikel: & Pembelajaran Bahasa Indonesia terkesan tidak menarik, membosankan, \\
Diterima: & tidak ada untungnya, ironisnya siswa merasa kesulitan dalam proses \\
11 Juni 2020 & pembelajarannya. Artikel ini mendeskripsikan (1) mengapa mata pelajaran \\
Direvisi: & Bahasa Indonesia tidak diminati; (2) bagaimana solusi untuk mengatasi \\
20 Juni 2020 & agar minat peserta didik terhadap pembelajaran Bahasa Indonesia muncul. \\
Disetujui: & Jenis penelitian ini kualitatif dengan teknik pengumpulan data wawancara \\
20 Juli 2020 & dan dokumentasi. Hasil penelitian menyimpulkan (1) tidak semua pendidik \\
& mata pelajaran bahasa Indonesia di sekolah vokasi berlatar belakang \\
Kata kunci: & keilmuan bahasa Indonesia (2) kreativitas tenaga pendidik dalam \\
bahasa Indonesia, & memecahkan persoalan dalam pembelajaran Bahasa Indonesia kurang; (3) \\
covid-19, kejuruan, & rendahnya persepsi peserta didik terhadap pembelajaran bahasa \\
pembelajaran inovatif & Indonesia.(4) solusi yang ditawarkan antara lain berupa pembelajaran \\
& dengan menggunakan teknologi gawai dan internat: membuat video \\
& rekaman misalnya rekaman membaca puisi, menulis karikatur untuk materi \\
& teks anekdot, dan membuat main mapping untuk materi teks eksposisi. \\
& Diperlukan penataan kembali guru mata pelajaran Bahasa Indonesia dan \\
& peninjauan kurikulum Bahasa Indonesia serta pembekalan mendesain \\
& media pembelajan yang inovatif.
\end{tabular}

\begin{tabular}{|c|c|}
\hline Article Info & ABSTRACT \\
\hline $\begin{array}{l}\text { Article history: } \\
\text { Received: } \\
\text { 11 June } 2020 \\
\text { Revised: } \\
\text { 20 June } 2020 \\
\text { Accepted: } \\
20 \text { July } 2020 \\
\text { Keyword: } \\
\text { Indonesian language, } \\
\text { covid-19, vocational, } \\
\text { innovative learning }\end{array}$ & $\begin{array}{l}\text { Indonesian language learning impression is not interesting, boring, no } \\
\text { advantageous, ironically the students feel difficulties in the learning } \\
\text { process. This article describes (1) Why the Indonesian language is not } \\
\text { interested; (2) How is the solution to overcome for appearing students' } \\
\text { interest in Indonesia language learning. This Type of research is qualitative } \\
\text { with data collection techniques, interviews and documentation. The } \\
\text { Results of the study conclusion, as follow (1) Not all Indonesian language } \\
\text { educators in vocational schools are in Indonesian language educational } \\
\text { background (2) The creativity of educators in solving the problems in } \\
\text { Bahasa Indonesia learning is weak; (3) Low student perception of } \\
\text { Indonesian language learning. (4) solutions offered as follow, learning by } \\
\text { using technology devices and Internet: making video recordings such as } \\
\text { reading poetry, writing caricatures for anecdotal text material, and creating } \\
\text { a main mapping for the exposition text. The requirement is rearrangement } \\
\text { Indonesian subject teachers and Indonesian curriculum review as well as } \\
\text { designing innovative learning media briefing. }\end{array}$ \\
\hline
\end{tabular}
DOI: http://dx.doi.org/10.30651/st.v13i2.5444 


\section{PENDAHULUAN}

Penempatan sektor pendidikan sebagai lokomotif munculnya sumber daya manusia yang kompetitif merupakan bagian dari proses skenario besar menuju penyiapan Indonesia sebagai negara industri sebab lembaga pendidikan ditempatkan sebagai persemaian manusia memiliki high skill digital talent pendukung pembangunan (Habibie, 2018). Oleh karena itu ketersediaan koherensi antara persekolahan, kurikulum, SKKNI dan kompetensi kerja harus tercipta secara harmoni dan saling memperkuat.

Tantangan besar era yang dikenal dengan fenomena disruptive innovation yang kita masuki dapat menyediakan jutaan lapangan kerja dan menjadi lompatan status ekonomi negara, namun fenomena tersebut akan berbalik menjadi petaka karena dampaknya jika tidak tersedia SDM yang berkualitas dan berkompetensi sebagai pelaku utamanya. Oleh sebab itu hadirnya sekolah yang berwawasan masa depan dengan dukungan materi pelajaran yang prospektif sangat diharapkan dan tumbuh menjadi wahana persemaian anak bangsa yang berkualitas (Ohoitimur, 2018).

Sesuai dengan Undang-undang Sistem Pendidikan Nasional Tahun 2003 pasal 15 disebutkan bahwa Sekolah Menengah Kejuruan (SMK) merupakan pendidikan menengah yang mempersiapkan peserta didik terutama untuk bekerja dalam bidang tertentu. Tujuan umum SMK adalah untuk meningkatkan keimanan dan ketakwaan peserta didik kepada Tuhan Yang Maha Esa dan mengembangkan potensi peserta didik agar memiliki akhlak mulia, pengetahuan dan wawasan kebangsaan yang luhur. Sedangkan tujuan khusus yaitu menyiapkan peserta didik dengan pengetahuan, kompetensi, teknologi, dan seni agar menjadi manusia produktif, maupun bekerja mandiri, mengisi lowongan pekerjaan yang ada di dunia usaha dan industri sebagai tenaga kerja tingkat menengah sesuai dengan kompetensi.

Melihat tujuan SMK tersebut (Sampun, Rahayu, \& Ariyadi, 2017) menyatakan bahwa tujuan pendidikan SMK sampai saat ini belum tercapai. Hal ini dikarenakan sistem pendidikan yang tidak memberikan ruang bagi peserta didik untuk mengembangkan potensi, bakat, dan minatnya, sehingga banyak lulusan SMK tidak mendapatkan pekerjaan yang sesuai dengan keahliannya dan banyak juga yang mengganggur. Hal ini dapat dilihat dari grafik berikut ini.

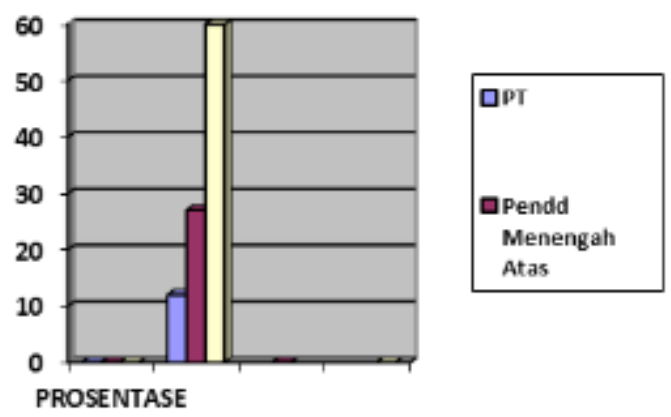

\section{Grafik1 Penggangguran Berdasarkan Pendidikan}

Pernyataan Hadam tersebut tentunya melihat keberhasilan tujuan pendidikan SMK secara umum sebagai output. Bagaimana dengan keberhasilan di bidang yang lebih spesifik, misalnya mata pelajaran Bahasa Indonesia. Bagaimana pun pembelajaran Bahasa Indonesia pasti berpengaruhi terhadap kompetensi peserta didik di bidang yang lainnya. Mengingat tujuan pembelajaran bahasa Indonesia di SMK sesuai Permendikbud tahun 2016 tentang 
Standar Isi Pendidikan Dasar dan Menengah yakni agar peserta didik memiliki kompetensi (1) sikap spiritual (menghayati dan mengamalkan ajaran agama yang dianutnya); (2) sikap social (menghayati dan mengamalkan perilaku jujur, disiplin, santun, peduli (gotong royong, kerjasama, toleran, damai), bertanggung jawab, responsif, dan pro-aktif melalui keteladanan, pemberian nasehat, penguatan, pembiasaan, dan pengondisian secara berkesinambungan serta menunjukkan sikap sebagai bagian dari solusi atas berbagai permasalahan dalam berinteraksi secara efektif dengan lingkungan sosial dan alam serta dalam menempatkan diri sebagai cerminan bangsa dalam pergaulan dunia; (3) kompetensi pengetahuan (memahami, menerapkan, menganalisis, dan mengevaluasi pengetahuan faktual, konseptual, prosedural, dan metakognitif pada tingkat teknis, spesifik, detil, dan kompleks dalam ilmu pengetahuan, teknologi, seni, budaya, dan humaniora dengan wawasan kemanusiaan, kebangsaan, kenegaraan, dan peradaban terkait penyebab fenomena dan kejadian pada bidang kerja yang spesifik untuk memecahkan masalah; (4) kompetensi keterampilan (menunjukkan keterampilan menalar, mengolah, dan menyaji secara: efektif, kreatif, produktif, kritis, mandiri, kolaboratif, komunikatif, dan solutif (Permendikbud, 2016).

Artikel ini bertujuan mendeskripsikan permasalahan pembelajaran bahasa Indonesia di sekolah kejuruan di Indonesia yang meliputi 1) mengapa mata pelajaran Bahasa Indonesia tidak diminati; (2) bagaimana solusi untuk meningkatkan minat peserta didik terhadap pembelajaran Bahasa Indonesia?

\section{METODE}

Penelitian ini menggunakan pendekatan deskriptif kualitatif dengan teknik pengumpulan data wawancara mendalam dan dokumentasi. Penggunaan pendekatan qualitative riset beralasan agar mendapatkan penjelasan yang lebih akurat dan presisi serta untuk menghasilkan konsep. Data dianalisis dengan deskriptif kualitatif dengan menggunakan teknik analisis mengalir dari (Miles \& Huberman, 1994) yang meliputi pengumpulan data, reduksi data, paparan data, verifikasi dan simpulan. Penggunaan teknik analisis tersebut karena disesuaikan dengan tujuan penelitian yang ingin mendeskripsikan dan menjelaskan hubungan yaitu antara kondisi pembelajaran bahasa Indonesia dengan keadaan siswa di sekolah (Mack, 2010). Sedangkan untuk mengecek keabsahan data digunakan triangulasi melalui komparasi kumpulan data dan menggunakan kunci sumber informasi (informan) mengingat riset ini bercorak studi kasus (Yin, 1991).

\section{HASIL DAN PEMBAHASAN Minat Belajar Bahasa Indonesia Rendah}

Bahasa Indonesia merupakan salah satu mata pelajaran ujian nasional, namun nasibnya tidak seperti mata pelajaran ujian nasional yang lain. Nilai mata pelajaran Bahasa Indonesia rendah, masyarakat tidak prihatin, tenang-tenang saja, namun bila hal tersebut terjadi pada nilai selain bahasa Indonesia (matematika, IPA) masyarakat menjadi ribut. Berbagai upaya dilakukan oleh masyarakat untuk mengantisipasi agar 
nilai mata pelajaran tersebut bagus. Hal ini senada dengan yang disampaikan oleh salah satu wali siswa bahwa wali siswa tersebut sibuk mencari guru les privat atau bimbingan belajar agar mata pelajaran ujian nasional mendapat nilai bagus, terutama mata pelajaran sains, sedangkan mata pelajaran bahasa Indonesia dianggap mudah sehingga tidak perlu mengikuti les privat.

Anggapan bahwa mata pelajaran bahasa Indonesia itu mudah, harusnya segera diluruskan. Sebenarnya bukan sulit atau mudahnya, tetapi seharusnya masyarakat melihat tujuan diajarkannya mata pelajaran ini. Salah satu tujuan pembelajaran bahasa Indonesia adalah peserta didik memiliki kompetensi menyimak, berbicara, membaca, dan menulis. Sebuah kemampuan yang harus dimiliki oleh setiap insan dalam bekal hidup bermasyarakat berbudaya dan bernegara. Penelitian Kumar (2014) menyatakan bahwa bahasa pertama dan lingkungan sangat berpengaruh terhadap pembelajaran bahasa kedua.

Berikut temuan-temuan di lapangan terkait mata pelajaran bahasa Indonesia.

\section{Pendidik yang Kurang Profesional}

Sesuai dengan hakikat bahasa dan pembelajaran bahasa, penekanan utama adalah menciptakan pembelajaran yang komunikatif. Dalam konteks ini, pembelajaran harus dilakukan dalam konteks komunikatif, yaitu aktivitas peserta didik difokuskan pada bagaimana peserta didik menggunakan bahasa dalam berkomunikasi. Baik berkomunikasi pada aspek ilmiah maupun tidak ilmiah
Beberapa faktor yang menyebabkan pembelajaran bahasa tidak berlangsung komunikatif : (1) latar belakang pengampu tidak sesuai dengan mata pelajaran, lima puluh persen pendidik mata pelajaran bahasa Indonesia berasal dari mata pelajaran lain. Studi kasus di salah satu SMK Negeri di Surabaya, diperoleh data sebagai berikut.

Tabel 1 Data Pendidik Mata Pelajaran

Bahasa Indonesia di Salah Satu SMK

\begin{tabular}{|l|l|l|}
\hline No & Guru & Bidang Ilmu \\
\hline 1 & Perempuan & $\begin{array}{l}\text { Bahasa } \\
\text { Indonesia }\end{array}$ \\
\hline 2 & Perempuan & $\begin{array}{l}\text { Bahasa } \\
\text { Indonesia }\end{array}$ \\
\hline 3 & Perempuan & $\begin{array}{l}\text { Bahasa } \\
\text { Indonesia }\end{array}$ \\
\hline 4 & Perempuan & $\begin{array}{l}\text { Bahasa } \\
\text { Indonesia }\end{array}$ \\
\hline 5 & Perempuan & Bahasa Inggris \\
\hline 6 & Perempuan & Bahasa Inggris \\
\hline 7 & Perempuan & Bahasa Inggris \\
\hline 8 & Perempuan & Bahasa Inggris \\
\hline 9 & Laki-laki & Bahasa Inggris \\
\hline \multicolumn{2}{|l|}{ Sumber: Wawancara dengan salah satu } \\
\end{tabular}

Data tersebut menunjukkan bahwa dominasi pendidik mata pelajaran Bahasa Indonesia adalah pendidik dengan latar belakang keilmuan yang berbeda. Tentu saja ini sangat berpengaruh dalam proses pembelajaran di dalam kelas. Guru bidang studi bahasa Indonesia dengan latar belakang bahasa Indonesia saja mengajarkan materi dalam kurikulum 2013 banyak yang mengeluh kesulitan. Materi teks yang masih relative awan bagi guru karena belum pernah dikenalnya dan juga karena saat berkuliah tidak pernah mendapatkan materi tersebut. Materi dalam kurikulum 2013 tidak pernah diterima guru saat duduk di bangku kuliah, sehingga guru tersebut harus belajar 
lagi. Itu pun hasilnya belum memuaskan. Apalagi bila mata pelajaran ini diajarkan oleh guru yang bukan bidangnya.

Pada umumnya guru kesulitan menanamkan ilmiah bahasa Indonesia seperti yang diamanatkan dalan kurikulum. Apalagi bagi pendidik dengan latar belakang yang jauh berbeda. Secara kasat mata, untuk mengajarkan mata pelajaran bahasa Inggris, tentunya harus bisa bahasa Inggris terlebih dahulu, sementara untuk bahasa Indonesia tidak demikian. Kalau hal ini disikapi menjadi hal yang sama tentunya pembelajaran bahasa Indonesia menjadi tidak menarik.

Sesuai Keputusan Direktur Jenderal Pendidikan Dasar dan Menengah No. 330/D.D5/KEP/KR/2017 disebutkan bahwa Kompetensi Inti dan Kompetensi Dasar SMK meliputi Mata Pelajaran Muatan Nasional (A) yaitu Pendidikan Agama dan Budi Pekerti, Pendidikan Pancasila dan Kewarganegaraan, Bahasa Indonesia, Matematika, Sejarah Indonesia, dan Bahasa Inggris dan bahasa asing lainnya. Muatan Kewilayahan (B) meliputi Seni Budaya dan Pendidikan Jasmani, Olahraga, dan Kesehatan. Dua muatan ini diberikan kepada peserta didik tanpa melihat bidang keahlian yang diambil. Sedangkan Muatan Peminatan Kejuruan (C) yang meliputi Dasar Bidang Keahlian (C1), Dasar Program Keahlian (C2), dan Kompetensi Keahlian (C3) mata pelajarannya disesuaikan dengan bidang keahlian yang dipilih oleh masing-masing peserta didik

Berdasarkan hasil wawancara dengan guru-guru SMK baik di Surabaya, Jakarta, dan Kalimantan diperoleh data bahwa peserta didik
SMK lebih berminat pada mata pelajaran kelompok C (Muatan Peminatan Kejuruan) daripada kelompok A (Mata Pelajaran Muatan Nasional). Peserta didik sangat antusias saat pembelajaran terkait dengan muatan peminatan kejuruan (C). Hal ini wajar saja karena untuk itu lah mereka studi. Kemudian bagaimana dengan mata pelajaran muatan nasional, terutama mapel Bahasa Indonesia. Sebuah mata pelajaran yang kurang melibatkan motorik, yang menjadi penciri sekolah vokasi. Akibatnya perhatian peserta didik terhadap pembelajaran muatan nasional seperti Bahasa Indonesia kurang. Pembelajaran semakin kurang kondusif lagi ketika melihat latar belakang pendidik tidak sesuai dengan bidang keilmuan.

Jumlah guru kurang memadai, dari contoh kasus ini ditemukan beban pendidik yang sangat banyak, yakni 51 jam/minggu. Dari hitungan jumlah rombel 51@4 jam sehingga ketemu 204 kemudian dibagi rata-rata dengan jumlah pendidik yang hanya 4 orang. Hal ini sangat tidak mungkin. Sehingga jumlah jam yang ada diberikan kepada pendidik yang berlatar belakang berbeda, yakni lima orang pendidik berlatar belakang pendidikan bahasa Inggris. Selain guru yang tidak sesuai bidang keilmuannya, pada umumnya pengetahuan pendidik bahasa Indonesia kurang memadai sehingga sangat perlu ditingkatkan. Kompetensi rendah ini tampak pada proses pembelajaran yang kurang kreatif dan inovatif. Terbuti bahwa pendidik lebih dominan menyampaikan pengetahuan bukan keterampilan apalagi berpikir kritis. Pengetahuan yang dimilikinya sangat terbatas karena kurang membaca (Pitaloka, 2018). Selain kurang 
membaca, referensi yang memperkaya keilmuan di bidang bahasa Indonesia sangat minim. Gambaran seperti ini sama dengan hasil penelitian yang dilaporkan oleh Suparno.

Dalam penelitiannya Suparno (1997:35) yang menyatakan bahwa: (a) tenaga pendidik masih cenderung memberikan penjelasan tentang bahasa, bukan pelatihan keterampilan berbahasa secara integrative dan komunikatif; (b) sebagian besar tenaga pendidik belum memiliki penguasaan yang memadai tentang taksonomi kemahiran berbahasa Indonesia (c) kelas yang besar berakibat tenaga pendidik mengikuti dinamika kelas bukan tenaga pendidik menciptakan dinamika kelas; (d) tenaga pendidik kurang menggunakan sumber lain selain buku teks; (e) masih banyak tenaga pendidik yang kebakuan bahasanya kurang ideal. (Ikawati, 1997). Sementara itu hasil penelitian yang dilakukan oleh Hanum (2013) bahwa pembelajaran e-learning yang diterapkan di salah satu SMK Swasta di Purwokerto saja menunjukkan bahwa tidak sepenuhnya pembelajaran e-learning efektif bagi semua guru di SMK tersebut. Hal ini salah satunya disebabkan belum optimalnya proses pembelajaran yang ada (Hanum, 2013).

\section{Materi, Metode dan Media Pembelajaran}

Pembelajaran mata pelajaran Bahasa Indonesia di beberapa daerah di Indonesia tidak jauh berbeda nasibnya. Hal ini seperti dilaporkan oleh Rochmatillah (2014) bahwa guru telah menyusun silabus dan Rencana Pelaksanaan Pembelajaran (RPP) untuk tujuh (7) kompetensi dasar (KD) yang harus disampaikan. Namun, dari ketujuh RPP yang dapat dilaksanakan hanya tiga (3) KD (Rochmatillah, 2014). Dipertegas juga oleh peneliti bahwa materi yang akan diajarkan di kelas XI terdiri atas beberapa teori yang berkaitan dengan beberapa kompetensi dasar yang telah ditentukan, tetapi dalam pelaksanaan pembelajaran, tidak semua materi tersampaikan sesuai RPP yang telah disusun oleh guru. Hal ini tentunya sebagai bukti bahwa pembelajaran Bahasa Indonesia di SMK bermasalah. Hanya saja di dalam penelitian Rocmatillah tidak dijelaskan permasalahan tidak tersampaikannya semua materi (KD) yang harusnya diselesaikan di semester tersebut.

Sekolah Menengah Kejuruan di Indonesia seharusnya mulai menerapkan revitalisasi di bidang penggunaan media video tutorial dalam pembelajaran (Sampun et al., 2017) Di era gobal dan di zaman IPTEK diperlukan reorientasi dalam penyelenggaraan pembelajaran, khususnya mata pelajaran Bahasa Indonesia. Peserta didik sudah saatnya untuk mengembangkan (Ikawati, 1997) kualitas pribadinya (jujur, disiplin, mandiri, kreatif, motif berprestasi, dan terbentuknya etos kerja), dan kemampuan strategis lainnya. Kompetensi ini menjadikan peserta didik mandiri, memunyai hubungan interpersonal, mampu bekerja sama, berpikir kreatif, mampu mengambil keputusan, mampu memecahkan masalah, mampu berkolaborasi, dan mampu memanajemen diri.

Pembelajaran Bahasa Indonesia tidak cukup dengan penyampaian informasi secara lisan (teoritis), diperlukan inovasi dan kreativitas sesuai dengan perkembangan ilmu pengetahuan 
dan teknologi khususnya IT. Strategi dan penggunaan IT menjadi salah satu alternative metode pembelajaran peserta didik secara aktif, dan didukung dengan pengembangan lingkungan sekolah secara professional, apalagi di era pandemic covid-19 ini. Pembelajaran menjadi di rumah saja (School From Home)

Selain itu, proses pembelajaran harus memperlakukan peserta didik menjadi subjek didik, karena akan sangat terbantu oleh computer based learning (CBL). Hal ini menjawab permasalahan yang ditemukan di beberapa SMK di Indonesia yang memperlakukan peserta didik sebagai objek yang kurang dilibatkan dalam pembelajaran dan pendidik merasa benar sendiri.

Penggunaan video tutorial akan memberikan pengalaman yang lebih dibandingkan dengan media lain, karena kedua indera penglihatan dan indera pendengaran sama-sama terlibat. Selain itu, media video tutorial juga dapat digunakan sebagai alternative solusi bagi keterbatasan sarana prasarana di sekolah. Sehingga peserta didik sebelum pembelajaran dimulai peserta didik dapat memelajari terlebih dahulu apa yang harus dilakukan sesuai yang ada dalam video. Misalnya pada kompetensi dasar teks prosedur, materi ini sangat menarik apabila disajikan dengan berbantukan video tutorial karena akan menarik peserta didik yang memang ada kecenderungan berminat ke hal-hal yang bersifat motorik.

Sutrisno dan $\begin{array}{r}\text { Siswanto } \\ (2016) \text { dalam penelitiannya } \\ \text { menemukan bahwa terdapat }\end{array}$

pengaruh yang signifikan persepsi penguasaan metode pembelajaran, media, dan motivasi belajar peserta didik terhadap hasil belajar peserta didik di sekolah vokasional. (Tang \& Sutrisno, 2012) Sofyan dan Komariah (2016) membuktikan bahwa model pembelajaran Problem Based Learning layak diterapkan di setiap mata pelajaran dalam implementasi kurikulum 2013 dan mampu meningkatkan kompetensi siswa dalam aspek hard skills maupun soft skills, dengan langkah awal guru harus mengubah pola berpikir, yang kedua perlunya pelatihan; ketiga menyiapkan materi ajar, media, dan bahan ajar (Sofyan, 2016).

Pembelajaran multibahasa berbasis bahasa ibu hanya dilakukan dalam tulisan, sementara dalam praktiknya sangat sulit, kecuali terdapat peningkatan kualitas fasilitas sekolah, pelatihan guru, materi pelajaran didemonstrasikan di masyarakat oleh pemerintah. Rekomendasi yang diberikan bahwa semua baik pemerintah maupun sekolah yang peduli harus menemukan cara untuk menyediakan materi pelajaran yang diperlukan, terutama buku untuk memastikan guru akan melaksanakan proses pembelajaran dengan sukses, pelatihan bagi guruguru harus diintensifkan; orang tua juga perlu mendapatkan sosialisasi, kembalikan hak anak untuk belajar bahasa sendiri dengan teori propnolingo ethagar; dan perlunya studi komparatif dan eksperimen antara lembaga pembelajaran swasta dan negeri untuk mengukur keberhasilan pembelajaran bahasa ibu secara kuantitatif. 
Dalam perspketif scaffolding kognitif, ditunjukkan bahwa penentuan capaian KD dalam mata pelajaran sering kurang memberi peluang berkembangan kognitif siswa sehingga materi cakupan yang diliput dalam KD seringkali kurang memiliki fokus highlight yang perlu dikembangkan lebih lanjut sehingga point-point penting pada materi kurang tertonjolkan secara ekplisit akibatnya siswa kurang mampu membedakan materi kunci dan materi suplemen (Seckstein, Spark, \& Jenkins, 2015).

Dengan video tutorial ini peserta didik bisa berulang-ulang menggunakan untuk mengulang materi yang kurang dipahami. Video tutorial ini bisa dibuat oleh pendidik dan juga oleh peserta didik. Peserta didik akan mendapatkan kesempatan untuk mengamati dan mengevaluasi pekerjaan baik pekerjaan pribadi maupun feedback pekerjaan temantemannya. Media ini juga dapat meningkatkan kompetensi interpersonal karena peserta didik dapat mendiskusikan apa yang telah mereka saksikan di video tutorial.

Berdasarkan hasil penelitian Francis M. Dwyer menyebutkan bahwa setelah lebih dari tiga hari pada umumnya manusia dapat mengingat pesan pesan yang disampaikan melalui tulisan sebesar $10 \%$, pesan audio $10 \%$, visual $30 \%$, dan apabila ditambah dengan melakukan, maka akan mencapai $80 \%$. Di sisi lain berdasarkan pengamatan terhadap kemampuan manusia dalam menerima dan mengingat informasi yang diterimanya, menurut Riset Computer Technology Research (CTR):

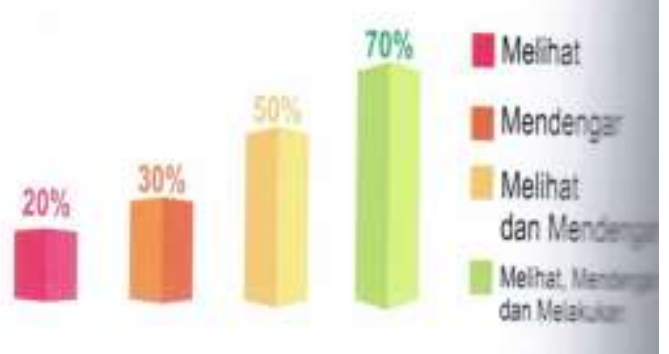

Grafik 2 Persentase Daya Ingat dengan Video Tutorial (Sampun et al., 2017)

Berikut gambar proses pembuatan video tutorial yang akan digunakan dalam proses pembelajaran.

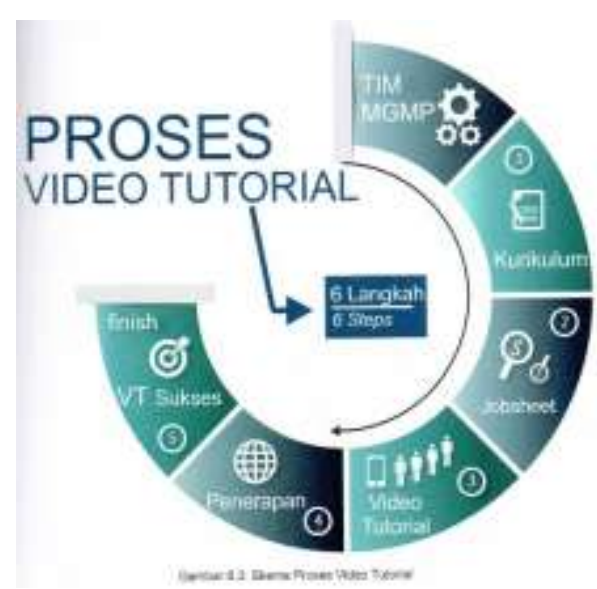

Gambar 1 Proses Video Tutorial (Sampun et al., 2017)

Pendidik di sekolah kejuruan di Indonesia seharusnya segera melakukan revitalisasi perubahan karakter agar sesuai dengan kebutuhan peserta didik dan dunia industry (Sampun et al., 2017) Sehingga filosofi yang dicanangkan oleh Bapak Pendidikan Ki Hajar Dewantara yakni guru digugu (dipercaya) dan ditiru (diteladani) dapat diwujudkan.

Pendidik sekolah kejuruan dalam menjalankan profesinya diharapkan mampu menerapkan 4 
ON, yakni Visi-ON, acti-ON, passiON, Collaborati-ON.

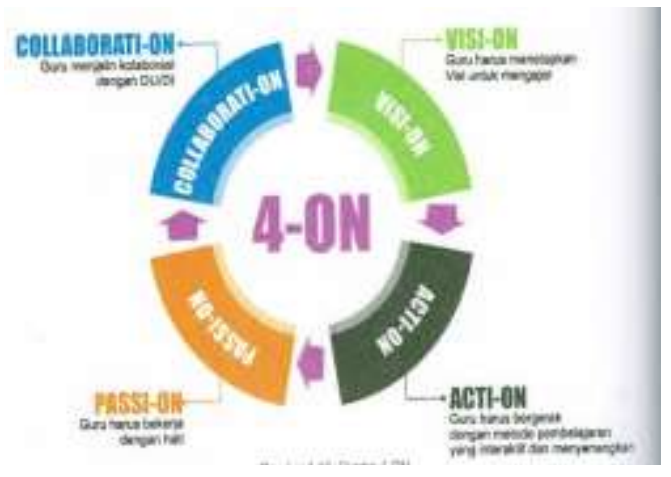

Gambar 2 Empat $O N$ (Sampun et al., 2017)

Visi-ON mengandung makna bahwa guru harus memunyai visi dalam mengajar bukan hanya diniati hanya transfer knowledge, melainkan juga memunyai tugas untuk membangun sikap dan karakter yang baik kepada peserta didik. Acti-ON merupakan kelanjutan vision. Apa artinya vision kalau tidak ada action. Vision memberi arah dan jalan. Action sebagai bukti bahwa seorang pendidik harus bergerak. Bergerak dalam proses pembelajaran sesuai karakter dan kecerdasan masing-masing peserta didik (multiple intelegen), sehingga pendidik juga harus kreatif dalam menggunakan metode pembelajaran serta media pembelajaran yang membuat peserta didik inovatif, kreatif dan tidak membosankan.

Passi-On maknanya bahwa pendidik harus membangun cinta, buka sekedar action, tetapi disertai passion. Tanpa passion mengajar seperti robot. Hanya melaksanakan tugas. Masuk kelas, keluar kelas, gugurlah tugas. Jangan action hanya karena tugas dan kewajiban, tidak ada penjiwaan, tidak ada gairah. Hasilnya pasti tidak maksimal dan suasana pasti menjenuhkan. Pembelajaran yang tidak didasari passion akan hampa, terjebak rutinitas, menjenuhkan, dan pastinya tidak kreatif/miskin kreativitas. Pendidik harus bekerja penuh keikhlasan. Orang yang ikhlas pasti tanpa pamrih. Pendidik ikhlas akan memberikan semua yang dimiliki agar peserta didik tumbuh dan berkembang, serta memiliki masa depan yang berkarakter positif.

$O N$ yang keempat adalah collaborate-ON. Collaborate-ON adalah kemampuan untuk menjalin kerja sama dengan pihak lain. Dengan kolaborasi tenaga yang dikeluarkan sedikit, namun hasil usaha yang didapat berlipat dan berkah melimpah. Kolaborasi pada dasarnya bekerja sama dengan pihak luar akan menghasilkan kekuatan dan keuntungan yang lebih besar. Pendidik yang mampu berkolaborasi dengan pihak luar dapat memberikan pembelajaran yang optimal sehingga menghasilkan luaran yang siap kerja.

Agar dapat melaksanakan empat $O N$ dengan pendidik harus rajin mengikuti kegiatan ilmiah seperti seminar, workshop, lokakarya, diskusi ilmiah atau kegiatan ilmiah lainnya baik di tingkat nasional maupun internasional. Kegiatan ilmiah ini tentu saja tidak hanya sebagai peserta tetapi juga sebagai pembicara tentunya. Dengan aktif mengikuti kegiatan ilmiah, akan tercipta atmosfer akademik yang sinergis dan holistik dalam berbagai ranah kehidupan ilmiah. Pendidik juga harus memiliki modal sebagai manusia yang meliputi modal intelektual (intellectual capital), modal social (social capital), modal metal (soft capital), dan modal agama (spiritual capital) agar mampu memberi pelayanan yang baik kepada peserta didik, dunia kerja (stake holder), dan masyarakat. Pendidik 
jangan cepat puas dengan apa yang dilakukan sekarang. Asal masuk kelas, mengajar seadanya dengan pengetahuan dan kemampuan paspasan, apalagi dengan konsep bahwa nilai bisa dibuat.

Kelemahan yang muncul dalam pembelajaran konvensional adalah kurangnya sajian di kelas yang melakukan inovasi dalam sistem sajian misalnya menggunakan blended learning yang terbukti lebih memunculkan motivasi belajar dan perluasan materi sehingga tercipta lebih dari sekedar one way teacher course (Guo, Justice, Kaderavek, \& McGinty, 2012). Penggunaan sistem face to face dalam kelas cenderung ditolak karena kurang mengarah pada tuntutan belajar baru yang lebih personalized dan cocok bagi individual siswa sehingga mereka merasa lebih terpenuhi kebutuhan belajarnya (Wang, 2018).

Guru bahasa dapat menerapkan variasi strategi instruksional untuk menghasilkan peluang baru bagi pembelajaran yang personal dan kreative. Sebab siswa sudah tahun bagaimana untuk mencari dukungan dan juga mempunyai kemampuan untuk mencari jalan keluar atas kesulitan belajarnya dengan memanfaatkan teknologi. Membangun motivasi siswa masih dipandang sebagai faktor penting dalam mengembangkan wawasan siswa dan suksesnya penerapan inovasi dalam sistem penyajian materi ajar terutama untuk menghasilkan metakognitve (Clayton \& Blumberg, 2010). Introspeksi diri dalam mengajar sangat jarang dilakukan kecuali mengandalkan dari pengawas sehingga kelemahan yang muncul dari praktik mengajarnya sangat jarang diketahui. Kemungkinan ini diprediksi menjadi salah satu penyebab rendahnya retensi yang merupakan hasil belajar yang diperoleh siswa. Dalam kajian (Krosnik, 2005) menunjukan bahwa hal ini merupakan cara yang genuine sense yang langsung berdampak pada retensi siswa yang mengarah pada peningkatan kepuasaan belajar. Sehingga akibatnya minat belajar terhadap suatu mata pelajaran menjadi meningkat.

Penelitian di Filipina mengidentifikasikan tantangan yang dihadapi guru dan strategi dalam implementasi program. Penelitian yang dilakukan oleh (Metile \& Williams, 2016) menggambarkan modifikasi model yang di dalamnya merangkul karakter multi-layered dari keanekaragaman linguistik melalui strategi program yang digerakkan oleh konteks. The adopted strategis demonstrate a localized realization of national policy and provide policy maker and implementers with a range of classroom realities and possible.

\section{Proses Pembelajaran}

Materi pembelajaran bahasa Indonesia di beberapa sekolah kejuruan di Indonesia masih dipisahkan antara materi linguistic dan materi sastra. Hal ini tentu saja sangat menjemukan dan tidak menarik. Seharusnya pembelajaran dilakukan secara terintegrasi. Keterampilan berbahasa yang idealnya disajikan secara terintegrasi belum dapat diimplementasikan secara optimal di kelas (Permendikbud, 2016). Aspekaspek kemahiran berbahasa masih disajikan secara terpisah. Misalnya, tenaga pendidik mengajarkan analisis unsur kebahasaan, seakan-akan tenaga pendidik hanya terfokus pada satu unsur tata bahasa saja. Walaupun buku pegangan peserta didik sudah 
menyajikan materi secara berkesinambungan. Sebenarnya apabila tenaga pendidik memahami hakikat pembelajaran integrative (tematis) maka pembelajaran bahasa dapat berlangsung secara alamiah sesuai dengan hakikat fungsi bahasa sebagai alat komunikasi. Pola implementasi integrative ini akan mendorong kemahiran berbahasa peserta didik secara baik.

Untuk memperlancar kegiatan pengajaran bahasa secara integrative diperlukanlah metode atau suatu rumusan sistem cara pengajaran karena metode pengajaran yang bervariasi karena langkah ini merupakan salah satu faktor yang berperan dalam pengajaran. Peran suatu metode sangatlah besar dalam suatu pengajaran dan bersangkutan juga dengan peserta didik yang menjadi objek pengajaran.

Dalam menerapkan metode pengajaran bahasa, ada beberapa hal yang sebaiknya diperhatikan terlebih dahulu oleh para tenaga pendidik yang antara lain adalah sebagai berikut: (1) Pembelajaran harus disesuaikan dengan kultur sosial dari objek peserta didik; (2) Menggunakan metode yang dianggap mudah oleh para peserta didik; (3) Melalui pendekatan yang sifatnya komunikatif dalam kegiatan belajar mengajar.

Pembelajaran bahasa Indonesia seharusnya diajarkan dengan menggunakan pendekatan systemic Fungsional Linguistik (SFL). SFL merupakan teori bahasa yang menekankan hubungan antara bahasa, teks [praktik sosial], dan konteks juga merupakan teori fungsional bahasa, yang menggambarkan bagaimana orang menggunakan bahasa untuk memaknai kata, mengerjakan sesuatu, dan untuk bertukar produk dan layanan dalam konteks (Halliday, M. A. K., Matthiessen, 2004). SFL merupakan teori sosial bahasa yakni penggunaan bahasa aktual/otentik dalam konteks (konteks budaya dan konteks situasi), dan systemik yang memaknai atau merasakan konteks, serta fungsional merupakan deskripsi fungsi bahasa.

\section{Peserta Didik}

Berdasarkan hasil pengamatan, persepsi peserta didik terhadap mata pelajaran bahasa Indonesia berada pada taraf yang rendah. Mereka menganggap pelajaran kelompok $\mathrm{A}$ tidak berhubungan langsung dengan minat belajar di sekolah kejuruan teknik yang mereka tekuni. Kondisi ini berdampak pada rendahnya motivasi peserta didik terhadap mata pelajaran bahasa Indonesia. Saat pelajaran berlangsung mereka lebih memilih tidur di tempat dengan alasan subjektif. Hal ini berimplikasi pada rendahnya hasil belajar peserta didik.

Penelitian yang dilakukan (Bachore, 2014) di Provinsi Zona Sidama Ethiopia menyatakan keberhasilan dan kegagalan pembelajaran berbasis bahasa memiliki hubungan dengan persepsi dan sikap masyarakat. Hal ini jika dikaitkan dengan fakta di Indonesia yang rata-rata masyarakat dalam hal ini orang tua siswa cenderung memiliki persepsi yang kurang terhadap pembelajaran bahasa Indonesia sehingga hal ini berdampak pada sikap peserta didik terhadap pembelajaran bahasa Indonesia.

Peserta didik di Kenya juga menunjukkan hal yang hampir sama dengan di Indonesia, bahwa peserta didik kurang menghargai bahasa sendiri daripada bahasa Inggris. Bahasa Inggris sangat dihargai baik untuk tujuan instrumental maupun 
integrative (Khejeri, 2014) merekomendasikan kepada pemerintah agar pemerintah mendorong pembelajaran bahasa ibu dan mempromosikan bahasa ibu agar digunakan baik sebagai bahasa pengantar maupun subjek dalam pembelajaran.

\section{Alternatif Solusi Pembelajaran}

Secara umum, dapat dikatakan bahwa minat dan motivasi rata-rata tenaga pendidik di Indonesia masih sangat kurang terhadap dunia sastra dan pembelajarannya. Oleh karena itu, tidak mengherankan alokasi waktu pembelajaran Bahasa dan Sastra Indonesia lebih dominan digunakan untuk bidang pembelajaran bahasa. Kendatipun dalam Kurikulum 2013, misalnya, telah disarankan agar pembelajaran bahasa dan sastra dapat berjalan secara proporsional, tetapi pada kenyataannya masih banyak tenaga pendidik tidak mengindahkan rambu-rambu tersebut. Masalahnya akan kembali menyangkut sikap, minat, dan motivasi tenaga pendidik itu sendiri terhadap bidang pembelajaran sastra.

Sebagian besar tenaga pendidik mata pelajaran bahasa Indonesia kurang menumbuhkembangkan minat dan kemampuan peserta didik dalam hal sastra.

Kelemahan senada juga dikemukakan oleh (Fink, 2013) bahwa guru sangat sedikit yang mencoba untuk membangun kemampuan siswa melakukan transfer ke dalam situasi baru, sehingga bahan ajar hanya sebatas sebagai banking concept yang berhenti pada memory akibatnya pelajaran tidak menarik dan tidak menghasilkan produk yang dirasakan.

Dalam pandangan teknologi kelemahan serupa juga muncul misalnya rendahnya penggunaan IT dalam penyajian materi yang menggunakan pendekatan blended learning akibatnya siswa hanya memperoleh materi terbatas di kelas tidak memiliki keluasan ilmu melalui penggunaan sumber virtual lainnya. Dalam kasus di sekolah kejuruan memperlihatkan kurangnya penggunaan tempat kerja (workplace) sebagai acuan pengayaan skill dan kognitif siswa yang dikemas dalam workplace learning. Kemasan materi yang ditempatkan di tempat kerja merupakan cara baru memotivasi siswa untuk belajar materi pelajaran sebagai bentuk contextualized dan collaborative (Wang, 2018). Sebenarnya tenaga pendidik dapat mengusahakan karya sastra peserta didik dimuat di media massa, dalam bentuk buku sastra, melalui media elektronik internet dan radio. Hal terakhir ini sangat bagus dalam menumbuhkembangkan potensi sastra yang ada dalam diri peserta didik. Mereka akan tertantang untuk membuat dan memublikasikan karya sastra mereka secara luas dan kontinyu. Kenyataan yang lebih memprihatinkan, sebagian besar tenaga pendidik tidak menjadi contoh sebagai orang yang aktif membuat dan memublikasikan karya sastra di media massa, dalam buku sastra, dan media elektronik.

$$
\text { Alternatif lain yang bisa }
$$
digunakan untuk mengatasi kekurangminatan peserta didik pada pembelajaran sastra yakni dengan melibatkan teknologi dalam hal ini gawai (android) dan internet. Tidak bisa dipungkiri saat ini semua peserta didik dapat dipastikan memiliki gawai. Penerapan teknologi ini misalnya pada materi "puisi". Kegiatan berselfi (berfoto ria) dan bervideo ini perlu 
dimanfaatkan dalam pembelajaran puisi. Peserta didik diberi tugas untuk membuat puisi, kemudian secara berkelompok membacakan puisinya tersebut. Mereka secara bergantian saling memvideo. Kegiatan ini pasti menyenangkan bagi peserta didik. Seperti yang dilakukan oleh salah satu sekolah kejuruan di Indonesia berikut ini.

Selain itu, sebagian besar tenaga pendidik bahasa dan sastra di sekolah juga sangat kurang memperkenalkan sastrawan muda yang kekinian kepada peserta didik. Oleh karena itu, wajar jika sebagian besar peserta didik tidak mengenal sastrawan baru yang lebih sesuai dengan kehidupan peserta didik. Seharusnya, tenaga pendidik tidak hanya memperkenalkan sastrawan lama kepada peserta didik karena banyak sastrawan muda yang lebih kekinian sesuai dengan realita kehidupan sekarang.

Topik bahasan lain, misalnya teks anekdot yang juga bisa dikerjakan dengan metode dramatisasi yang divideokan, hasilnya tampak pada gambar berikut ini.

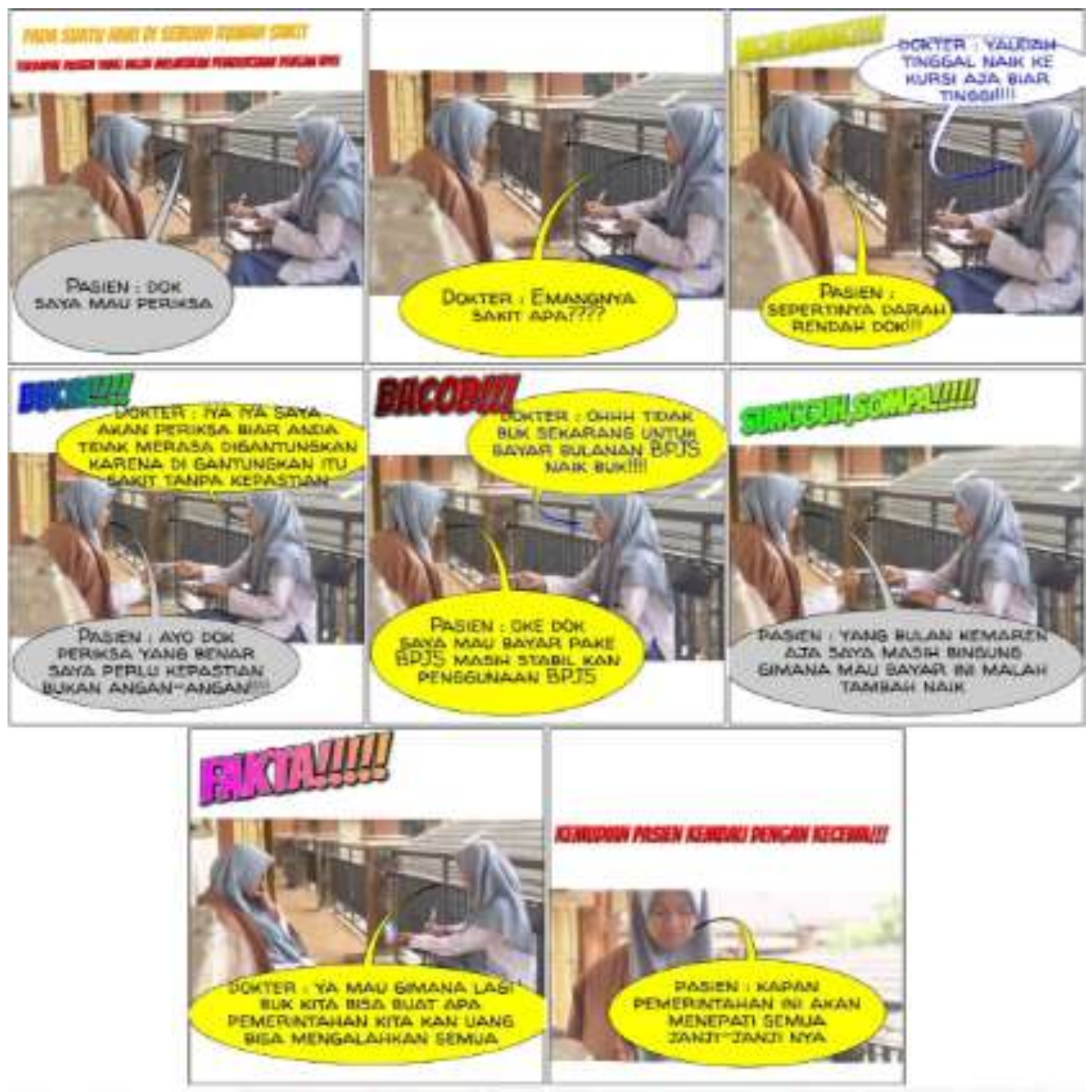

Gambar 3 Pembelajaran Topik Teks Anekdot 
Topik lainnya misalnya, Teks Eksposisi, pendidik dapat menugasi peserta didik membuat main mapping.
Seperti yang dilakukan oleh salah satu sekolah di Jawa Timur berikut ini.
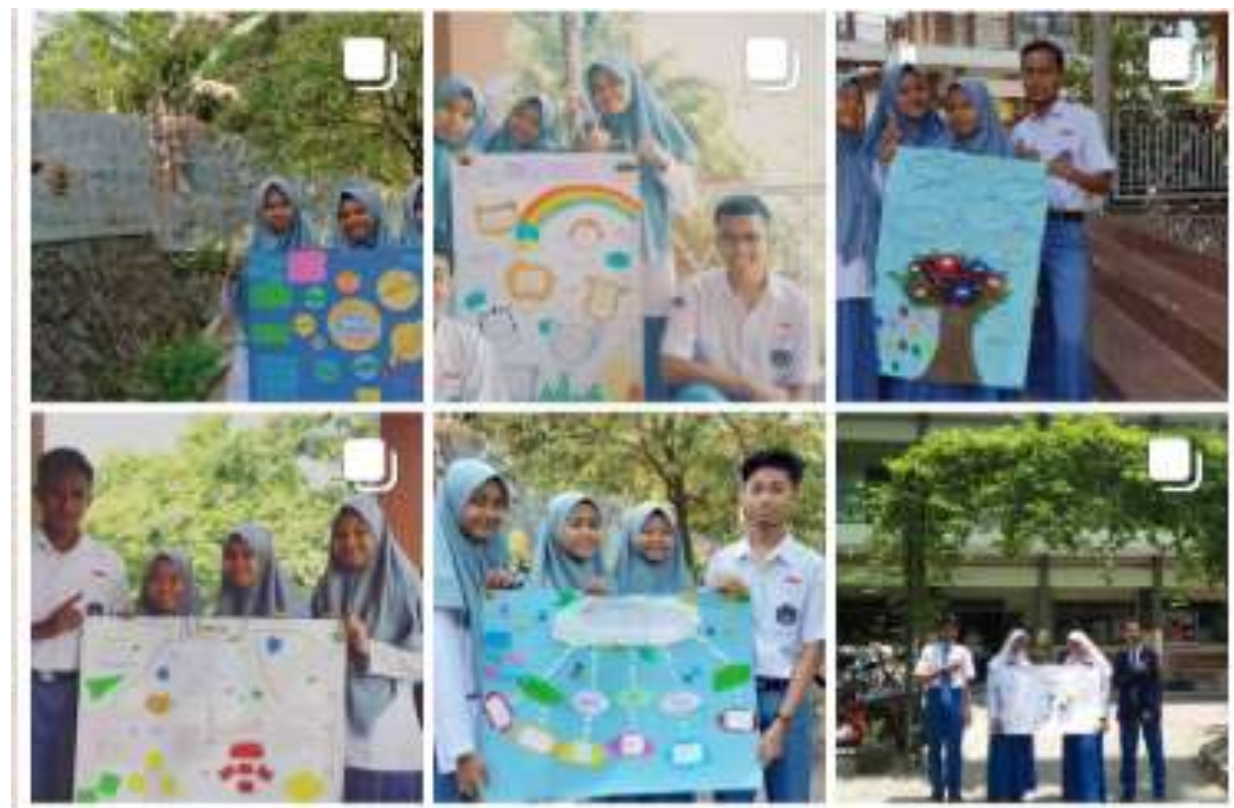

Gambar 4 Pembelajaran Teks Eksposisi

\section{PENUTUP}

Berdasarkan hasil pembahasan, hasil penelitian ini dapat disimpulkan bahwa permasalahan pembelajaran bahasa Indonesia di sekolah kejuruan selain disebabkan keterbatasan jumlah pendidik, namun juga keterbatasa kompetensi yang dimilik. Pendidik yang professional sangat dibutuhkan di era sekarang ini. Yang dimaksudkan professional antara lain pendidik harus memiliki menguasai teori belajar dan menguasai berbagai metode dan media pembelajaran yang inovatif utamanya metode dan media pembelajaran yang sesuai dengan karakter peserta didik kejuruan utamanya yang berbasis teknologi. Apalagi dengan adanya program belajar dari rumah di era pandemic covid-19 sangat urgent penguasaan teknologi pembelajaran daring, untuk itu pendidik harus menguasai learning management system serta video conference dan teleconference.

\section{UCAPAN TERIMA KASIH}

Terima kasih disampaikan kepada kepala SMK Negeri 1 di Surabaya yang telah memberi izin kepada peneliti untuk mengadakan penelitian dan terima kasih juga diucapkan untuk guru mata pelajaran Bahasa Indonesia di SMK di Jakarta, di SMK Balikpapan dll. yang telah membantu peneliti dalam mengumpulkan data. Semoga jasa baik Bapak dan Ibu menjadi amalan sholeh. Amin

\section{DAFTAR PUSTAKA}

Bachore, M. M. (2014). "Learners' Success in Mother Tongue Based Classroom Instruction and the Attitudes and Perceptions of School Communities". International Jounal of Sociology 
of Education, 3(2), 118-135. https://doi.org/10.4471/rise.2014. 09

Clayton, K., \& Blumberg, F. (2010). "The Relationship between motivation, learning strategies and choice of environmen whether traditional or including an online component". British Journal of Educational Technology, 41. https://doi.org/10.1111/j 14678535.200900993

Fink, L. D. (2013). Creating Significant Learning Experiences. An Integrated Approach Designing College Courses. Alexandria: Jossey Bass.

Guo, Y., Justice, L. M., Kaderavek, J. N., \& McGinty, A. (2012). "The literacy environment of preschool classrooms: Contributions to children's emergent literacy growth". Journal of Research in Reading. https://doi.org/10.1111/j.14679817.2010.01467.x

Habibie, I. (2018). Arah Indonesia 4.0. Jakarta: Wantiknas.

Halliday, M. A. K., Matthiessen, C. M. (2004). Halliday, M. A. K., \& Matthiessen, C. M. An Introduction to Functional Grammar. London: Arnold.

Hanum, N. S. (2013). "Keefektifan ELearning Sebagai Media Pembelajaran ( Studi Evaluasi Model Pembelajaran E-Learning Smk Telkom Sandhy Putra Purwokerto ) The Effectiveness of E-Learning As Instructional Media ( Evaluation Study of ELearning Instructional Model
Insmk Telkom". Jurnal Pendidikan Vokasi, 3(1), 90-102.

Ikawati, A. (1997). "Problematika Dalam Aplikasi Kaidah Berbahasa Indonesia". Likhitaprajna. Jurnal Ilmiah. Fakultas Keguruan Dan Ilmu Pendidikan, 18(2), 79-89.

Khejeri, M. (2014). "Teachers Attitudes Towards the Use of Mother Tongue as a Language of Instruction in Lower Primary Schools in Hamisi District, Kenya". International Journal of Humanities and Social Sciences, 4(1).

Krosnik, C. (2005). Making a diffrence in Teacher Education through self study. Netherlands: Springer.

Mack, N. (2010). Qualitative Research Methods. North Carolina: Family Health International. Hal. 3). North Carolina: Family Health International.

Metile, R. A., \& Williams, A. B. (2016). "The Challenge of Implementing Mother Tongue Education in Linguistically Diverse Contexts: The Case of the Philippines". The Asia-Pasific Education Researcher., 23(5-6), 781-78.

Miles, M. B., \& Huberman, M. (1994). An Expanded Sourcebook. Qualitative Data Analysis. Thousand Oak: Sage Pblications.

Ohoitimur, J. (2018). "Tantangan bagi Perkembangan Ilmu Pengetahuan dan Peluang bagi Lembaga Pendidikan Tinggi Johanis Ohoitimur". Respons, 23(02), 143-166. Retrieved from 
file://C:/Users/sujinah/AppData/

Local/Temp/553-Article Text729-1-10-20190624-1.pdf

Permendikbud. (2016). "No Title". Retrieved from https://bsnpindonesia.org/wpcontent/uploads/2009/06/Permend ikbud_Tahun2016_Nomor021_La mpiran.pdf

Pitaloka, P. P. (2018). "Memupuk Minat Baca Anak", 12(02), 2636.

Rochmatillah, D. (2014). Proses Pembelajaran Mata Pelajaran Bahasa Indonesia pada Siswa Kelas Xi Sekolah Menengah Kejuruan Negeri 2 Klaten.

Sampun, H., Rahayu, N., \& Ariyadi, A. N. (2017). Strategi Implementasi Revitalisasi SMK (10 langkah Revitalisasi SMK). (M. Bakrun \& Dkk, Eds.) (1st ed.). Jakarta: Direktorat Pembinaan Sekolah Menengah Kejuruan Direktorat Jenderal Pendidikan Dasar dan Menengah Kementerian Pendidikan dan Kebudayaan.
Seckstein, S., Spark, L., \& Jenkins, A. (2015). Are e-books effective tools for learning? Reading speed and comprehension: iPad®i vs. paper. South African Journal of Education, 35(4), 1-14.

Sofyan, H. (2016). "Pembelajaran Problem Based Learning Dalam Implementasi Kurikulum 2013 Di SMK Problem Based Learning In The 2013 Curicullum", 6(3), 260271.

Tang, M., \& Sutrisno, S. (2012). "Implementasi Sekolah Menengah Kejuruan Bertaraf Internasional". Teknologi dan Kejuruan.

Wang, M. (2018). E Learning in the worksplace, A Performance oriented approach beyond technology. Springer InternationalPublising. https://doi.org/10.1007/978-3319-64532-2_5

Yin. (1991). Applications of Case Study research. Woshington DC.: Cosmos Corp. 